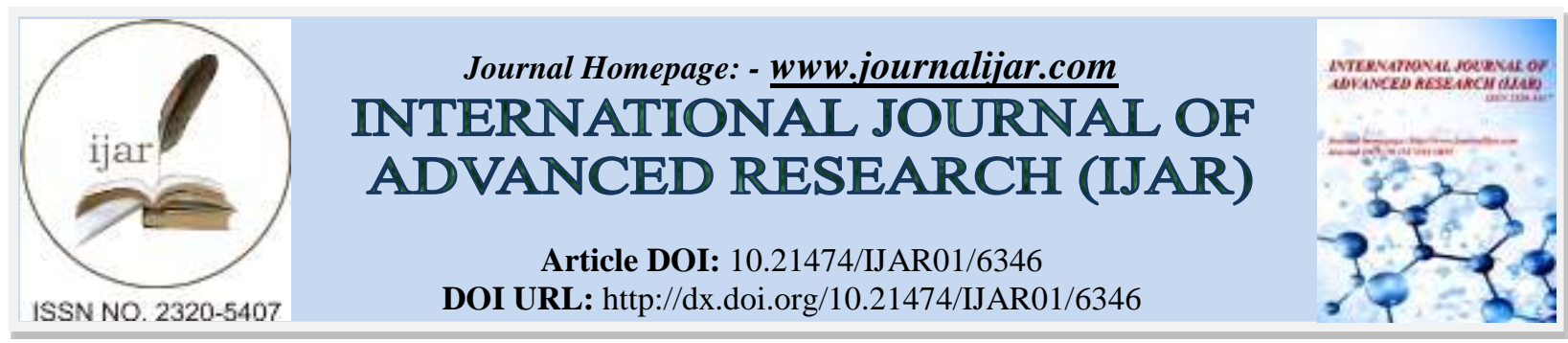

RESEARCH ARTICLE

\title{
EDUCATION INTERVENTIONS IN PRIMARY CARE TO IMPROVE CHRONIC PAIN OUTCOMES.
}

1. DNP, FNP, MSN.

Kathleen E. Rogers, Pamela Aselton, Gabrielle Abelard and UMass Amherst.

2. $\mathrm{PhD}, \mathrm{MPH}, \mathrm{FNP}-\mathrm{BC}$.

3. PMHCNS, BC.

4. UMass Amherst, College of Nursing.

\section{Manuscript Info}

\section{Manuscript History}

Received: 19 November 2017

Final Accepted: 21 December 2017

Published: January 2018

Key words:-

Chronic Pain, Nursing Interventions, Health Education Outcomes, NonPharmacological, Acceptance-Based, Self-Care.

\begin{abstract}
Background: Chronic pain is a burden in terms of patient distress, social and work disability, diminished quality of life, and increased healthcare costs. In the treatment of chronic pain, non-pharmacological interventions offer patients self-management strategies to improve function, coping and adaptation skills. Improved health outcomes through education in these methods may be more beneficial than reliance on prescription pain medication.

Aims and Methods: Chronic pain patients benefit from enhanced knowledge to manage pain through health education, support tools and information on complementary therapies, with non-pharmacological, acceptance-based health education. The aim of this paper is to summarize the non-pharmacological tools that patients may use to relieve chronic pain.

Results: Interventions such as stretching, ergonomics, exercise, as well as other alternative approaches offer enhanced pain control.

Conclusions: Nurse-led interventions in chronic pain education offer solutions for clinical practice with non-pharmacological, acceptancebased health education. Chronic pain patients benefit from ergonomics and posture training, stretching discussions, and complementary modalities.

Copy Right, IJAR, 2018. All rights reserved.
\end{abstract}

\section{Introduction:-}

In the United States chronic pain is one of the most prevalent conditions treated in primary care with consequences that impact the individual, healthcare systems, and populations. Chronic pain is defined as unpleasant sensory and emotional experiences arising from actual or potential tissue damage, which occurs for three months or longer (North American Nursing Diagnosis, 2014). As one of the most common physical symptoms treated in primary care, pain contributes to patient distress, social and work disability, decreased quality of life, and increased healthcare costs (Gaskin, 2011). It can result in sleep disturbance, stress, prescription abuse, and depression. Primary care providers are motivated to improve pain care and support delivery of tools that enhance pain management when faced with the national opioid crisis. Individuals with pain managed with opioids should be aware of the importance of incorporating alternative pain management interventions. 


\section{Review of the Literature:-}

Reports were sought by searching MEDLINE, psycLIT, CINAHL, EMBASE, NIH, Cochrane, and EBSCO using search terms non-cancer chronic pain, chronic low back pain, and chronic pain. A review of current research in the treatment of chronic pain suggests that health professionals traditionally focus on biomedical views of pain, using pharmacology first, and may not address potential non-pharmacological approaches, such as education to change attitudes towards pain (Rosenblum, Marsh, Joseph, \& Portenoy, 2008).

Interventions teaching patients cognitive and behavioral skills, through nursing interventions, are related to overall patient improvement (Stevens, 2013). Research in non-cancer chronic pain management indicates that there is a need for further implementation of health promotion. Interventions teaching patients cognitive and behavioral skills, with pain modifying interventions, are related to overall patient improvement.

Chronic pain management practices vary in clinical practice and are complicated by provider knowledge gaps, time restrictions, lack of patient coping skills and self-management tools, inconsistencies in health education as well as problems of long term opioid use and dependence (Armijo-Olivio, Stiles, Hagen, Biondo, \& Cummings, 2012). Evidence suggests that the management of chronic pain in primary care fluctuates and that education with selfmanagement interventions offer improvements in overall care (Williams, 2016).

Non-pharmacological interventions offer an approach to improve patient's quality of life through ongoing education. Patients suffering from chronic pain may undergo long periods of treatment, experience changes in their lifestyle and difficulty with the medications used to manage pain (Lalonde et al., 2015). Offering optimal health promotion to manage chronic pain empowers the patient to engage in self-care activities that result in improvement in individual experiences.

Over 100 million adults in the United States have chronic pain and are impacted with limitations in life, and functional status (Kroenke et al., 2013). The average cost of healthcare, due to chronic pain, ranges over $\$ 300$ billion. Lost productivity estimates that the total financial burden in the US population at over $\$ 600$ billion (Gaskin, 2011). Improving chronic pain outcomes and accurately identifying pain intensity are important factors in the development of outcome measures regarding pain reduction (Bauer, Thielke, Katon, Unutzer, \& Arean, 2014). Chronic pain constitutes challenges in the absence of an effective cure; strong communication and collaboration between the client and provider can improve functional capacities and quality of life (Brevivik, Collett, Ventafridda, Cohen, \& Gallagher, 2006). Psychological factors in chronic pain treatment such as coping skills, quality of life issues, and disability status are important factors that may be addressed. A strong association between chronic pain and psychopathology indicates pain may be associated with depressive or anxiety disorders, substance abuse, and personality disorders. Psychological and social factors are related to the perception of pain, particularly as pain becomes more chronic. In the maintenance of pain behavior and support, clinicians should include cognitive behavioral therapy (CBT) referral for the patient (Ware, Bruckenthal, Davis, \& O’Connor-Von, 2011).

Management of chronic pain, with effective treatment modalities and alternatives to opioid medications, involves a comprehensive process in lowering pain intensity (Bueno \& Pina, 2008). Alternative modalities can have significant impact on pain outcomes and studies have shown interventions for chronic pain management include health coaching education (Anderson \& Taylor, 2011). Further evaluation and education is necessary to improve client outcomes and empower patients' abilities to succeed at modifying chronic pain and improving self-care (Turk, Wilson, \& Swanson, 2011)

\section{Chronic Pain Management:-}

Collaborative partnerships with patients and their families through integration of health education and selfmanagement tools incorporating interventions that facilitate pain management focused on complementary alternative medicine methods may assist in managing chronic pain. Posture demonstrations, complementary treatment modality education, stretching and breathing exercises, with additional information regarding the importance of sleep, nutrition, and exercise are helpful for patients with chronic pain. A summary of evidence-based health education focusing on ergonomics, healthy lifestyle behavior, and pain self-care management strategies is presented in Table I. 
Table 1:- Suggested Patient Led Interventions for Chronic Pain

\begin{tabular}{|c|c|}
\hline $\begin{array}{l}\text { 1. Use of Heat, } \\
\text { Cold }\end{array}$ & $\begin{array}{l}\text { Heat: Use a hot water bottle, heating pad, or gel pack. Apply heat for no longer than } 10 \text { minutes } \\
\text { at a time. Do not apply anything that is uncomfortably warm, to avoid burning your skin. } \\
\text { Cold: Use wrapped ice cubes (towel, etc.) or gel pack. Apply for no longer than } 10 \text { minutes at a } \\
\text { time. You may find switching between heat and cold helps, wait } 10 \text { minutes in between, and } \\
\text { ending with cold may be beneficial. }\end{array}$ \\
\hline $\begin{array}{l}\text { Deep Breathing, } \\
\text { Relaxation }\end{array}$ & $\begin{array}{l}\text { Slow, deep breaths, belly breathing, can help to reduce anxiety. Relaxation techniques, hypnosis, } \\
\text { calm breathing; gentle movements such as tai chi and yoga may help reduce stress and pain. } \\
\text { http://www.health.harvard.edu/mind-and-mood/relaxation-techniques-breath-control-helps-quell- } \\
\text { errant-stress-response }\end{array}$ \\
\hline Posture & $\begin{array}{l}\text { Standing and sitting up straight, rolling shoulders back, toes pointed forward when standing or } \\
\text { sitting. } \\
\text { http;//www.mayoclinic.org/healthy-lifestyle/multimedia/back-pain/sls-20076817 }\end{array}$ \\
\hline Stretching & $\begin{array}{l}\text { Lie on your back and lift legs to your chest, hugging the leg at the knee. Standing, stretching, } \\
\text { reaching upwards. }\end{array}$ \\
\hline $\begin{array}{l}\text { Acupuncture, } \\
\text { Massage, PT }\end{array}$ & $\begin{array}{l}\text { Massage may be effective in relieving pain; acupuncture has demonstrated pain relief, and } \\
\text { physical therapy may give relief from pain. At home, rolling a tennis ball between a wall and the } \\
\text { painful area may offer some relief and massage sore muscles. } \\
\text { http://www.webmd.com/balance/guide/acupressure-points-and-massage-treatment }\end{array}$ \\
\hline $\begin{array}{l}\text { Music, Reading, } \\
\text { Meditation } \\
\text { Therapy }\end{array}$ & $\begin{array}{l}\text { When experiencing pain, find something pleasant, can help to relax. } \\
\text { http://www.mayoclinic.org/tests-procedures/meditation/in-depth/meditation/art-20045858 }\end{array}$ \\
\hline Sleep & $\begin{array}{l}\text { Sleep affects pain. The amount of sleep each person needs depends on many factors, including } \\
\text { age. For most adults, } 7 \text { to } 8 \text { hours a night can be the best amount of sleep. } \\
\text { http://www.mayoclnic.org/healthy-lifestyle/adult-health/expert-answers/how-many-hours-of- } \\
\text { sleep-are-enough/faq-20057898 }\end{array}$ \\
\hline Nutrition & $\begin{array}{l}\text { Servings of fresh fruit, vegetables and lean protein (chicken, beef, tofu), greens and legumes may } \\
\text { help lower levels of pain. Eating more fruits and vegetables and cutting back on processed foods } \\
\text { offers health benefits. } \\
\text { http://www.mayoclinc.org/healthy-lifestyle/nutrition-and-healthy-eating/basics/nutrition- } \\
\text { basics/hlv-20049477 }\end{array}$ \\
\hline Exercise & $\begin{array}{l}\text { If recommended by your provider, walking and active-passive movements, may reduce muscle } \\
\text { spasm, increase blood flow and help to relieve pain. } \\
\text { http://www.mayoclinic.org/healthy-lifestyle/fitness/in-depth/exercise/art-2004838 }\end{array}$ \\
\hline Water Therapy & $\begin{array}{l}\text { Using water for treatment, either by means of thermal springs, hot tub, or baths may reduce } \\
\text { stress, increase blood flow, relax muscles, and reduce pain. }\end{array}$ \\
\hline Aromatherapy & $\begin{array}{l}\text { The use of essential oils from plants into the air, may improve mood, relieve pain, and promote a } \\
\text { sense of relaxation. Scents may reduce stress and tension. Not recommended, synthetic oils or } \\
\text { use in patients with breathing problems. } \\
\text { http://www.mayoclinic.org/healthy-lifestyle/consumer-health/expert-answers/aromatherapy/faq- } \\
\text { 20058566 }\end{array}$ \\
\hline $\begin{array}{l}\text { TENS } \\
\text { (Transcutaneous } \\
\text { Electrical Nerve } \\
\text { Stimulation) }\end{array}$ & $\begin{array}{l}\text { TENS applies mild electrical stimulation to the skin to manage pain and should be recommended } \\
\text { by your provider. } \\
\text { http://www.mayoclinic.org/tens/img-20006686 }\end{array}$ \\
\hline Magnesium & $\begin{array}{l}\text { A vitamin supplement, } 200-300 \mathrm{mg} \text { of magnesium, may decrease pain through muscle relaxation, } \\
\text { if recommended by your provider, who may include calcium and vitamin D. } \\
\text { http://www.mayoclinic.org/drugs-supplements/magnesium-supplement-oral-route-parenteral- } \\
\text { route/proper-use/drg-20070730 }\end{array}$ \\
\hline
\end{tabular}

By defining interventions that improve the functional status of the patient, this augments a patient's quality of life and empowers both the patient and the provider to tailor a patient-centered pain management approach. Patient dissatisfaction supports the requisite for improved pain management and the importance of educating individuals to discuss their pain with providers (Schlaeger et al., 2017). 


\section{Implementation of Evidence into Practice:-}

This review supports the need for pain management interventions in the treatment of chronic pain. Undertreated chronic pain impacts life quality and increases healthcare costs.

Increasing provider and patient education, changes in public policy, and enhancements in pain management support standardization of approaches in the evaluation and treatment of chronic pain in primary care.

\section{References:-}

1. Anderson, J. G. \& Taylor, A. G. (2011). Effects of healing touch in clinical practice a systematic review of randomized clinical trials. Journal of Holistic Nursing, 29 (3), 221 - 228.

2. Armijo-Olivio, S., Stiles, C. R., Hagen, N. A., Biondo, P. D., \& Cummings, G. G. (2012). Assessment of study quality for systematic reviews: a comparison of the Cochrane Collaboration Risk of Bias Tool and the Effective Public Health Practice Project Quality Assessment Tool: methodological research. Journal of evaluation in clinical practice, 18 (1), 12-18.

3. Bauer, A. M., Thielke, S. M., Katon, W., Unutzer, J., \& Arean, P. (2014). Aligning health information technologies with effective service delivery models to improve chronic disease care. Preventative medicine, 66, 167-172.

4. Brevivik, H., Collett, B., Ventafridda, V., Cohen, R., \& Gallacher, D. (2006). Survey of chronic pain in Europe: prevalence, impact on daily life, and treatment. European Journal of pain, 10 (4), 287-288.

5. Bueno, D. C., \& Pina, P. M. (2008). Effectiveness of nursing intervention for adult patients experiencing chronic pain: a systematic review. JPI Library of Systematic Reviews, 6 (12), 3-13.

6. Dorflinger, L., Kerns, R. D., \& Auerbach, S. M. (2013). Providers' roles in enhancing patients' adherence to pain self-management. Translational behavioral medicine, 3 (1), 39-46. Retrieved from http://doi.10.1007/s13142-0120155-z.

7. Dworkin, D. C., Turk, K. D., Wyrwich, B. D., Cleeland, C. S., Farrar, J. T... \& Brandenburg, N. (2011). Interpreting the clinical importance of treatment outcomes in chronic pain clinical trials: IMMPACT recommendations. The Journal of Pain, 9 (2), 105-121.

8. Gaskin, D. J., Richard, P. (2011). The Economic Costs of Pain in the United States. Institute of Medicine (US) Committee on Advancing Pain Research, Care, and Education. Relieving Pain in America: A Blueprint for Transforming Prevention, Care, Education, and Research. Washington DC: National Academies Press (US).

9. Hawk, K.F., Vaca, F.E, \& D'Onofrio. Reducing Fatal Opioid Overdose: Prevention, Treatment, and Harm Reduction Strategies. The Yale Journal of Biology and Medicine, 88(3), 235-245.

10. Kroenke, K., Outcalt, S., Krebs, E., Bair, M. J., Wu, J., Chumbler, N. \& Yu, Z. (2013). Association between anxiety, health-related quality of life and functional impairment in primary care patients with chronic pain. General hospital psychiatry, 35, (4), 359-365.

11. Lalonde, L., Choiniere, M., Martin, E., Levesque, L., Hudon, E., Belanger, D... \& Laliberté, M. C. (2015). Priority interventions to improve the management of chronic non-cancer pain in primary care: a participatory research of the ACCORD program. Journal of Pain Research, 8, 203-215.

12. Mills, S., Torrance, N., \& Smith, B. H. (2016). Identification and Management of Chronic Pain in Primary Care: A Review. Current Psychiatry Reports, 18, 22. Retrieved from http://doi.org/10.1007/s11920-015-0659-9.

13. North America Nursing Diagnosis Association (NANDA) (2014). Chronic Pain Nursing Interventions and Rationales. NANDA Nursing. Retrieved from http://nandanursing.com/chronic-pain-nursing-interventions-and-rationales.html.

14. Rosenblum, A., Marsh, L. A., Joseph, H., \& Portenoy, R. K. (2008). Opioids and the Treatment of Chronic Pain: Controversies, Current Status, and Future Directions. Experimental and Clinical Psychopharmacology, 16 (5), $405-$ 416. Retrieved from http://doi.org/10.1037/a00013628.

15. Schlaeger, J.M., Roach, K., Golas, M., Takayama, M., \& Wilkie, D. J. (2017). Treatment-Seeking Behaviors of Persons With Rheumatoid Arthritis. Journal of Holistic Nursing. Retrieved from: doi:10.1177/089801011793539.

16. Stevens, K. R. (2013). The Impact of Evidence-based Practice in Nursing and the Next Big Ideas. The Online Journal of Issues in Nursing, 18 (2). Retrieved from: doi:10-3912/OJIN.Vol18No02Man04.

17. Turk, D. C., Wilson, H., \& Swanson, K. S. (2011). The biopsychosocial model of pain and pain management. New York: Cambridge University Press.

18. Ware, L. J., Bruckenthal, P., Davis, G. C., \& O’Connor-Von, S. K. (2011). Factors that Influence Patient Advocacy by Pain Management Nurses: results of the American Society for Pain Management Nursing Survey. Pain Management Nursing, 12 (1), 25-32. Retrieved from DOI: 10.1016/j.pmn.2009.12.001

19. Williams, A. C. (2016). Defeating the stigma of chronic pain. Pain, 157 (8), 158. 